Article

\title{
Road Investment and Traffic Safety: An International Study
}

\author{
Francisco Calvo-Poyo * ${ }^{*}$, José Navarro-Moreno $₫$ and Juan de Oña $(\mathbb{1}$ \\ TRYSE Research Group, Department of Civil Engineering, University of Granada, ETSI Caminos, Canales y \\ Puertos, c/Severo Ochoa, s/n, 18071 Granada, Spain; janavarro@ugr.es (J.N.-M.); jdona@ugr.es (J.d.O.) \\ * Correspondence: fjcalvo@ugr.es; Tel.: +34-958-249-452
}

Received: 16 July 2020; Accepted: 4 August 2020; Published: 6 August 2020

check for updates

\begin{abstract}
The aim of this study is to analyse whether the economic resources invested in roads-both investment in construction and expenditure on maintenance and conservation-have any influence on road fatality rates. Since this is a complex problem, and because there are many factors that can influence the fatality rate, other variables related to specific transport, socioeconomic and meteorological factors are also considered. The study was carried out using a panel data model, modelling road mortality as a function of 12 variables. The scope of the study is international, focusing on the interurban road network. Data were collected from 23 European countries for the period 1998-2016. The main results obtained are that both expenditure on road maintenance and conservation and the proportion of motorways in the total road network contribute to reducing road mortality. Contrariwise, greater investment in construction leads to an increase in the fatality rate.
\end{abstract}

Keywords: road safety; road accidents; investment in roads; maintenance and conservation expenditure

\section{Introduction}

Road accidents are one of the main negative externalities of road transport, causing suffering and great losses of human capital to society as a whole. Therefore, for road transport to be sustainable (economically and socially), a reduction in the number of accidents is necessary.

Globally, road traffic accidents are the 8th cause of unnatural death among people of all ages, yet the 1st cause of death for the population from 5 to 29 years old, and the 4th for the age group between 30 and 44 [1]. In the context of the European Union (EU), 25,047 people died as a result of a road accident in 2018, representing reductions of 1\% compared to 2017 and $4 \%$ accumulated for the EU over the last 5 years [2]. Despite the improvement, it appears practically impossible to achieve the objective set out in the European Road Safety Strategy of reducing traffic fatalities by $50 \%$ by 2020 (compared to the 2010 figure). Nevertheless, in keeping with the long-term philosophy promoted by the EU, a further target consists of a $50 \%$ reduction in the number of deaths and serious injuries by 2030, the latter indicator being included for the first time in the strategic road safety plans [3].

An important feature of road fatality figures is that most correspond to accidents on interurban roads. In 2016, for example, $62 \%$ of all fatalities occurred on interurban roads. On the other hand, the typology of accidents on urban roads is different, most involving running over people $(71 \%$ of pedestrian deaths occurred on urban roads, according to data for 2016) [4]. The scope of our study is the interurban road network because of this higher mortality rate.

Apart from the human losses that accidents bring, road accidents are not economically sustainable. Studies estimate that road accidents come at a cost equivalent to about 3\% of the Gross Domestic Product (GDP) in countries with a high GDP per capita [5,6]. The European Commission calculates this cost based on the sum of four components: the human cost, the loss of production, medical costs 
and administrative costs. Deaths on the road entail a cost of 3,273,909 euros per person [7], meaning the cost associated with the loss of life in 2018 would be 82 billion euros.

One way to reduce road accidents is by improving the road network (improving the layout, transforming conventional roads into motorways, etc.), and keeping them in the best possible condition. In the European Union, investment in transport infrastructure has historically represented around 1\% of the GDP [8]. However, the financial crisis of 2008 and the sovereign debt crisis of 2011-2012 have reduced these investments. In 2016, total investment in road construction was approximately EUR 69 billion and maintenance expenditure was EUR 38 billion, a level of investment and expenditure comparable to that of 1995 [9]. The period of reduced road investment curiously coincides with a slight decline in the number of deaths on EU roads, just 4\% between 2013 and 2018. The question therefore arises as to whether there is a link.

Therefore, this study aims to explore the possible relationship between infrastructure conditioning factors and road fatalities. To assess the conditioning factors of roads, the economic resources behind them will be considered, that is, investment in construction and expenditure on maintenance and conservation. It has to be noticed that the economic resources invested in roads can have opposite effects: on one hand, increasing the accident rate (road improvements can generate increased vehicle speed), while on the other hand, reducing the accident rate (enhancing safety by transforming two-lane conventional roads into motorways, widening hard shoulders, improving signalling, etc.). In addition, since there are many factors that bear an influence on the accident rate, other transport-specific, socioeconomic and meteorological variables will be considered. To this end, a panel data model is developed with data from different countries. The selected countries belong to the group of High Income Countries according to the World Bank [10], and most are members of the EU.

This article is structured as follows: firstly, a review of the state-of-the-art is carried out in Section 2, focusing on studies that include road infrastructure investment variables. Section 3 gives the data used in the study and its source. Section 4 explains the methodology used. Section 5 shows the results and discusses them. Finally, Section 6 puts forth the main conclusions of this study.

\section{State of the Art}

There is extensive literature on the factors affecting road accidents. In The Handbook of Road Safety Measures [11], one chapter is dedicated to explaining these factors, including a review of some articles highlighting them.

With regard to the factors most closely related to roads, studies at the micro level (specific roads, sections, etc.) usually include aspects related to layout, curvature, lane and shoulder widths, visibility or consistency in design [12-19]. Apart from its design characteristics, the state of conservation of a road can influence the occurrence of accidents. Chan et al. [20] used various indicators of the state of conservation (rut depth, roughness index and pavement functionality index) together with other variables (luminosity, atmospheric conditions and traffic intensity) to try to predict traffic accidents.

Aspects such as atmospheric conditions and luminosity [20-22] or the maintenance of roads during winter [23,24] are included under the conditions of the road environment. Finally, aspects such as speed, intensity and composition are usually considered to bear impact on accident occurrence [12,20,25-27]. In terms of human behaviour, age is often considered to be a very influential factor [12,28], along with gender [29,30], alcohol consumption [31] and fatigue [32,33], among others.

Considering road accident studies in wider contexts (countries, regions, etc.), traffic indicators (vehicle-km, speed, fuel consumption, etc.), population characteristics (inhabitants, age, etc.), socioeconomic aspects (consumption rates, per capita income, unemployment rate, educational level, etc.) and others (such as alcohol consumption) are variables usually included in macro studies. Hedlund et al. [34] concluded that economic, demographic and alcohol consumption were the most influential factors in their study of a decline in road accidents. Hoxie et al. [35] referred to petrol and gas prices, unemployment rates, population, labour force and production rates to explain the same reduction in accidents. Partyka [36] used population, labour force and unemployment to predict 
accidents. Wagenaar [37] found that the unemployment rate was associated with a small reduction in traffic accidents. Joksh [38] estimated an almost linear relationship between changes in industrial production rates and traffic accidents. Kopits and Cropper [39] related road traffic crashes to per capita income. According to Hakim et al. [40], the unemployment rate may be the most common variable used to explain traffic accidents from a macroscopic point of view (increases in the unemployment rate being associated with a decrease in road accidents). In turn, Kweon [41] found an inverse relationship between the annual variation of economic indicators, unemployment rate and the consumer price index, and the occurrence of road accidents in Virginia (United States).

In line with the above, many studies adopt a macroscopic point of view to analyse the causes behind the evolution of accident rates on road networks. Lloyd et al. [42] studied the reduction in the number of accidents on British roads between 2007 and 2010, and concluded that it was associated with a reduction in the level of traffic, the percentage of heavy vehicles, the number of young male drivers, speed and alcohol consumption. Similarly, Rivas et al. [43] looked into traffic fatalities in Spain, relating them to exposure to risk and a series of socioeconomic, structural, climatic and risk behaviour variables. The results indicated a positive relationship between the number of accidents and the rate of alcohol consumption and the volume of heavy traffic, and a negative relationship with the proportion of high-capacity roads and the level of education and culture. Michalaki et al. [44], distinguishing between roadway and hard shoulder crashes, concluded that accidents on the hard shoulder were much more severe than those on the road. Cafiso et al. [45] developed several accident models using exposure, geometry, consistency and road context variables. They found that increases in the traffic volume, driveway density and roadside hazard rating were related with an increase in the number of accidents with injuries, while the opposite was true for the number of speed differentials, higher than $10 \mathrm{~km} / \mathrm{h}$, in a homogeneous section. Focusing on the roadside context, Elvik [46] realized a meta-analysis of 32 studies that evaluated the influence of median barriers and guardrails on traffic safety. Based on those studies, he estimated a $20 \%$ reduction of the chance of suffering a fatal accident due to the effect of median barriers, while the estimate for the guardrails was a $45 \%$ reduction. He [47] linked the decrease in the number of accidents in the United States between 2003 and 2013 to the unemployment rate (finding an inverse relationship) and disaggregating according to different types of accidents. Noland and Zhou [48] linked the decrease in the number of accidents in the United States from 1984 to 2014 to a decrease in family income, an increase in inequality, legal measures, improvements in the road network, an increase in population, and a decrease in economic activity. In a study involving members of the Organisation for Economic Cooperation and Development (OECD), Wegman et al. [49] explored the relationship between the business cycle and changes in the number of accidents. They found that economic recession, explained by lower economic growth, lower gross domestic product and increased unemployment, was associated with a decline in the number of accidents.

Following the inclusion of economic aspects in road safety studies, and more specifically of economic resources invested in roads, Fridstrøm and Ingebrigtsen [50] incorporated investment in road construction and maintenance into their study on road accidents in 18 Norwegian provinces, finding a favourable effect between maintenance expenditure and improved road safety. With respect to investments in construction, their results were contradictory, and varied according to the ownership of the road. They also obtained significant correlations for a number of independent variables relating to exposure, weather conditions, daylight, road network, changes in accident reporting, vehicle inspection, traffic fines and alcohol consumption. Aparicio et al. [51] conducted a nationwide study in Spain on the main factors affecting traffic accidents. They considered 19 variables grouped into 10 categories: exposure to risk, infrastructure (including expenditure on maintenance and conservation, and the percentage of high-capacity roads in the road network), meteorology, driver experience, economic variables, calendar, vehicle fleet, police surveillance, technological improvements in vehicles and legal changes. In terms of infrastructure, they observed that a greater proportion of high-capacity roads was related to a reduction in the number of accidents; however, no conclusive results were obtained with regard to expenditure on maintenance and conservation, which appeared to be related to 
decreases in accidents with injuries and increases in accidents with deaths. Authors Albalate et al. [52], in addition to including investment variables, infrastructure characteristics (high-capacity road or conventional road, lane width) and a series of other control variables, adopted variables for legislative changes in their models. In doing so, they found an inverse relationship between investment in road maintenance and deaths. The same relationship was also found with the motorisation rate, the level of unemployment, the number of doctors per capita and the percentage of people over 65 .

Nguyen-Hoang and Yeung [53] studied the effects of investments in highway construction and maintenance in 48 US states with regard to mortality. They included a series of variables reflecting socioeconomic, regulatory, meteorological, exposure and driver characteristics, and arrived at the conclusion that investments in both highway construction and maintenance have a positive effect on the decrease in mortality. These authors also obtained significant relationships for the following variables: vehicle miles travelled, total lane mileage, ratio of trucks, maximum speed on rural roads, seatbelt laws, precipitation index, temperature index, gross state product per capita, income per capita and unemployment rate. Recently, Sánchez et al. [54] carried out a study in Spain on the influence of provincial characteristics on traffic accidents on interurban roads by analysing different economic, technical, social and legislative variables. Among the economic variables, they included investment in road construction and investment in replacement. Found to be significant, with a negative relation to accidents, were investments made in both the construction and the replacement of roads. They also obtained significant and negative relationships for another series of variables: the implementation of the penalty points system, the volume of traffic, the motorisation rate, the annual variation in population density, the unemployment rate, and the proportion of high capacity roads.

In conclusion, despite the existence of numerous studies dealing with road safety and the factors that affect it, no studies published to date have determined the influence of economic resources invested in roads and in road safety from an international perspective, considering different countries. Similar studies tend to focus on separate regions within one same country. Our contribution analyses data from 23 European countries.

\section{Data}

The choice of countries and the study period were conditioned by the availability of data on investment in road construction and maintenance. In an attempt to combine the largest number of countries with the longest time period, the countries finally included in the study were: Austria, Belgium, Croatia, Czech Republic, Denmark, Estonia, Finland, France, Germany, Italy, Ireland, Latvia, Lithuania, Luxembourg, Netherlands, Norway, Poland, Portugal, Slovakia, Slovenia, Spain, Sweden and the United Kingdom. The availability of data led us to focus on 1998 to 2016. Given the existence of numerous explanatory factors for road accidents, as just seen in the literature review, it is possible to incur in a specification error problem by not including some significant factors in the model. Therefore, additional variables were included to account for: exposure, specific transport characteristics, and socioeconomic and meteorological conditions.

Regarding the dependent variable to be incorporated in the model, Hakkert and Braimaister [55] recommend using a ratio according to the level of exposure, an approach previously used in other studies $[43,54,56,57]$. Along this line, Papadimitriou et al. [58] assessed various risk indicators together with exposure data available at the European level. Following the recommendations of both, the present study considers mortality rate as a dependent variable. This rate is defined as the number of deaths per billion passenger-km.

Data on deaths on interurban roads-defined as any person killed immediately or dying within 30 days as a result of an injury accident [59]—were used in this dependent variable. The possibility of using other models with the total number of accidents or seriously injured persons as the variables was ruled out because there were insufficient data, disaggregated by type of road, for the set of countries and the time series selected. Exposure is considered to be one of the factors contributing most to the number of road accidents-accounting for at least $50 \%$ of the variation in the number of deaths [60]. 
The relationship of this factor with mortality has been widely studied in the literature $[12,13,50,61,62]$. Thus, as a control of the level of exposure within the dependent variable, the number of passenger-km will be used.

With regard to the independent variables, firstly, the economic resources invested in road infrastructure were included as a control for the main hypothesis put forward in the study. The low level of disaggregation of the investment data limited to the two variables to be included in the model: investment in construction of new roads, and expenditure on maintenance and conservation. Because the frequency in reporting this type of data is usually annual, the same frequency was adopted for the rest of the variables.

Three variables are included as transport-specific factors: the proportion of motorways, the motorisation rate, and petrol consumption per vehicle. The proportion of motorways has been included in numerous studies $[43,51,52,54,63]$, and an inverse relationship with mortality is expected, since the characteristics and quality of these roads lend themselves to higher levels of traffic safety. The motorisation index reflects, in a sense, the level of prosperity of a country. This variable is also found in the literature $[41,50,53,54]$. The variable of fuel consumption per vehicle is included as an indicator of the intensity of use of the vehicle fleet.

In terms of socioeconomic variables, due to the strong influence of economic cycles on the occurrence of accidents $[39,61,64,65]$, the GDP and unemployment rate variables are included. GDP serves to grasp a country's level of economic development. The unemployment rate reflects variations in economic cycles. In order to characterize the population composition of each country, it was decided to include the variables of population density and the proportion of people over 65 years of age, both being related to road safety according to previous studies [54,66-68].

Finally, weather conditions are widely considered in the literature as an explanatory factor for road accidents. This relationship has been documented with different effects, depending on the frequency of the data: annual, monthly, daily or even in real time $[43,44,51,59,69]$. Given that our analysis is conducted at the macro level with annual data, and that the most widely used meteorological parameter in the literature is rainfall $[69,70]$, average annual rainfall is included as a variable in the model.

Other variables initially considered for inclusion in the model were per capita alcohol consumption and educational level. In the case of alcohol consumption, although data were available in the World Bank database [71], interpretations derived from these data would be questionable, as they refer to the total population (over 15 years) and do not necessarily represent the attitudes of drivers regarding alcohol consumption. In the case of educational level in the various countries, insufficient data were encountered for the entire time series.

The definition of the variables used and the main descriptive statistics for them are found in Tables 1 and 2. The sources of the data used in the analysis are described below:

Table 1. Definition of variables.

\begin{tabular}{cc}
\hline Dependent Variable & \\
\hline Fatal_pkm & Fatalities per Billion Passenger-km \\
\hline Independent Variables & \\
\hline Road_inv_km & Road investment per kilometer in thousand euros \\
Road_maint_km & Road maintenance expenditure per kilometer in thousand euros \\
Prop_motorwa & Proportion of motorways, in \% \\
Mot_index & Motorization index, in passenger cars per 1000 inhabitants \\
Petrol_car & Oil and petrol consumption, in tonnes, per car \\
GDP & Gross Domestic Product, in billion euros \\
Unemploy & Unemployment rate, as a percentage of the labour force \\
Den_populat & Density of population, inhabitants $/ \mathrm{km}^{2}$ \\
Prop_elder & Proportion of elderly population (Age $>65)$ \\
Precipit & Average depth of rain water during a year, in mm \\
\hline
\end{tabular}


Table 2. Descriptive statistics of variables.

\begin{tabular}{ccccc}
\hline Variable & Mean & SD & Min & Max \\
\hline Fatal_pkm & 7.67 & 5.83 & 1.47 & 35.30 \\
Road_inv_km & 21.91 & 35.19 & 0.033 & 279.89 \\
Road_maint_km & 8.29 & 10.64 & 0.25 & 83.76 \\
Prop_motorwa & 2.48 & 3.92 & 0.00 & 21.42 \\
Mot_index & 446.18 & 97.75 & 199.39 & 678.41 \\
Petrol_car & 1.58 & 1.02 & 0.73 & 7.51 \\
GDP & 589.13 & 807.17 & 9.61 & 3110.79 \\
Unemploy & 8.77 & 4.20 & 1.90 & 26.10 \\
Den_populat & 126.42 & 99.20 & 13.64 & 408.88 \\
Prop_elder & 16.14 & 2.30 & 10.78 & 22.04 \\
Precipit & 920.72 & 280.55 & 445.70 & 2266.78 \\
\hline
\end{tabular}

\subsection{Data on Fatalities}

The United Nations Economic Commission for Europe (UNECE) database was taken as reference for the number of fatalities [72]. Data were also obtained from the Community Road Accident Database (CARE) [73], the International Traffic Safety Data and Analysis Group (IRTAD) [74] and the Ministerstvo-Vnútra of Slovenia [75], completing the database for the period under study.

\subsection{Data on Exposure}

Data on passenger-km have been obtained from the EU's DG Mobility and Transport [76].

\subsection{Data on Investment and Conservation and Maintenance}

The database taken as a reference for these two variables is that of the International Transport Forum [77]. However, as the time series is not complete for the countries and period selected, nor is it disaggregated into construction and maintenance costs, complementary data from the following national institutions were taken: Bundesministerium für Verkehr und digitale Infrastruktur, Germany [78,79]; Ministerie van Infrastructuur en Waterstaat, Netherlands [80,81]; Ministério Da Economía y Infraestruturas de Portugal, Portugal [82-87]; Ministerio de Transportes, Movilidad y Agenda Urbana, Spain [88]; Ministerstvo Dopravy, Czech Republic [89]; and Trafikverket, Sweden [90].

All monetary values were converted to constant 2015 prices through the OECD consumer price indexes [91].

\subsection{Socioeconomic Data}

Data on GDP were obtained from the World Bank. For the unemployment rate, the Eurostat database was consulted, supplemented in the cases of Estonia and Croatia with data from the World Bank. For the variables population density and the proportion of persons over 65 years old, the data on total population and number of persons over 65 available from Eurostat were used [71,92].

\subsection{Meteorological Data}

The European Climatic Energy Mixes (ECEM) dataset of the Copernicus Climate Change Service was used to obtain average annual rainfall [93].

Figure 1 shows the evolution of the average values of the variables. The figures for fatalities per billion passenger-km reflect, at a general level, the great progress made in terms of road safety throughout the period under consideration. The overall average for the countries falls from 13.10 in 1998 to 3.83 in 2016. The lowest number of fatalities per billion passenger-km occurs in 2015 in Norway, with a rate of 1.47. The highest number occurs in 1998 in Latvia, with 35.30. From then on, as part of the convergence with other EU countries, Latvia manages to gradually reduce this figure to 9.21 in 2016. 

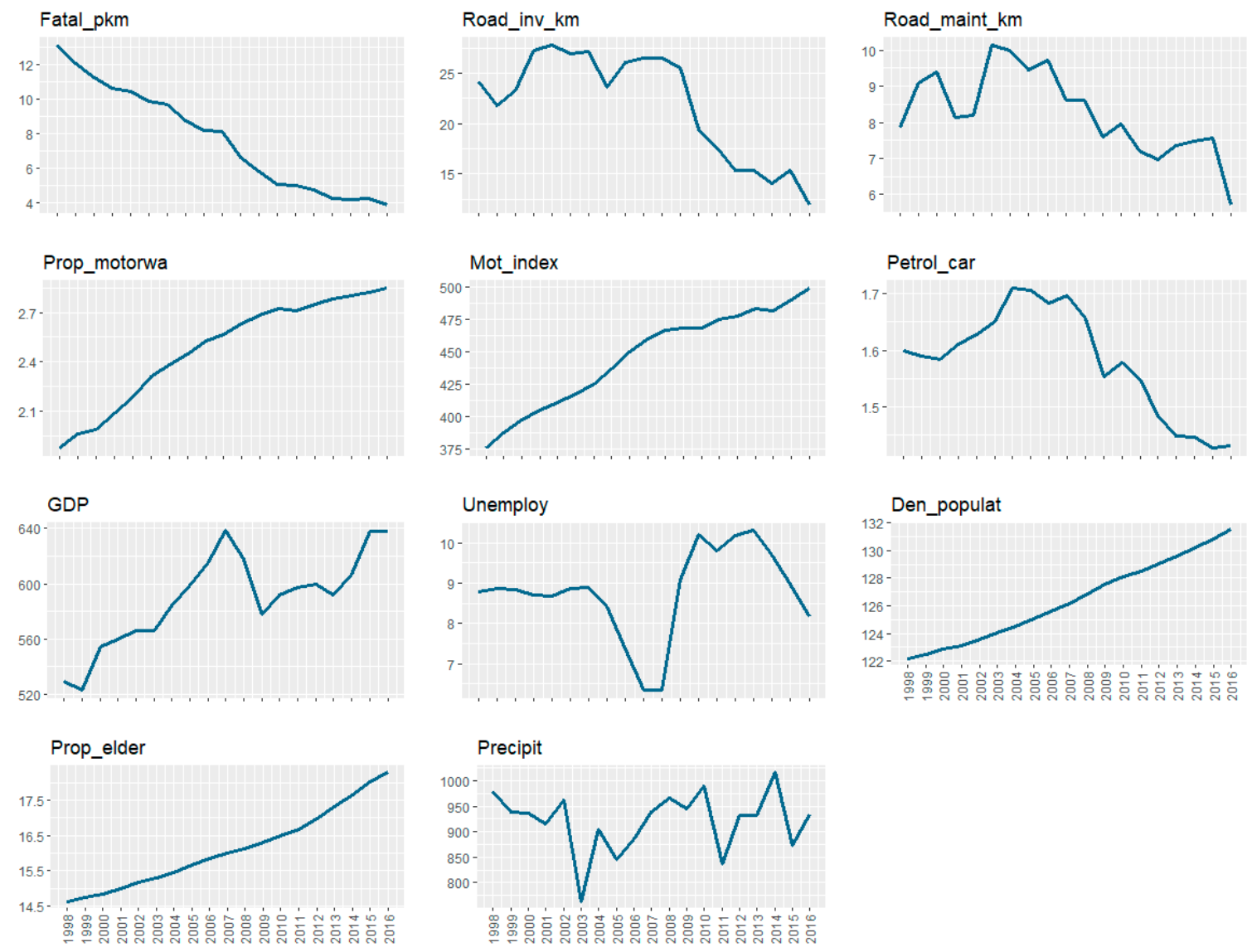

Figure 1. Evolution of the average values of the variables.

In terms of investment, there is a period of generalised growth up to 2009, after which a decrease in investment and expenditure begins, which continues until 2016. It should be noted that the minimum value of investment in road construction per kilometre of network corresponds to the one made by Latvia in 1998, framed in a period of transition for the Baltic countries, from a planned economy to a market economy. On the other hand, the highest figure of investment in road construction per kilometre of network is seen in 2001 in Portugal, this year coinciding with the maximum value placed on general infrastructure by the country, $5.81 \%$ of GDP, in a decade in which the average annual percentage of investment in road infrastructure was the highest since the 1980s, 1.52\% of GDP [94].

The figures for expenditure on conservation and maintenance per kilometre of network showed that the minimum value corresponds to France in 1998. At that time France already had a high level of road infrastructure development, with $9303 \mathrm{~km}$ of motorways and 971,064 km of other paved roads. The highest values of expenditure on conservation and maintenance per kilometre of network are seen for Italy, their maximum being attained in 2003.

Regarding transport-specific factors, the proportion of motorways varies from $0 \%$ in Latvia over the whole time series to $21.4 \%$ in Portugal in 2015. Data on the motorisation rate show an east-west divide between the countries considered, though as the time series progresses, the gap narrows. The average of the dataset is 446 passenger cars per thousand inhabitants; the extreme values are presented by Latvia in 1998, with 199, and by Luxembourg in 2016, with 678 . The average fuel consumption per vehicle is 1.59 tonnes per year. Luxembourg concentrates the highest values over the whole time series, reaching a maximum in 2005 with a consumption of $7.51 \mathrm{tn}$ per vehicle. In contrast, the minimum value of $0.74 \mathrm{tn}$ per vehicle is produced in Poland in 2014.

Analysis of socioeconomic data showed the countries with the highest GDP to be Germany and Great Britain, with Germany in 2016 reaching a maximum value of 3110.80 billion euros. The Baltic countries show the lowest GDP values, the minimum of 9.61 corresponding to Latvia in 1998. 
The unemployment rate varies from minima for Luxembourg around the year 2000 to maxima reached in Spain between 2011-2015; the extreme values are 1.90\% for Luxembourg in 2001 and 26.1\% for Spain in 2015. The highest population densities are found in the Central European area, as opposed to the densities of the Nordic countries (except Denmark). The maximum value of $409 \mathrm{inh} / \mathrm{km}^{2}$ corresponds to the Netherlands in 2016, whereas the lowest value of $14 \mathrm{inh} / \mathrm{km}^{2}$ pertains to Norway in 1998. As for the population composition of the countries, a general process of ageing is reflected, and the minimum value of the percentage of people over 65 is seen for Ireland in 2008, while the maximum value is in Italy in 2016 , respectively $10.77 \%$ and $22.03 \%$.

Finally, and with regard to the data on precipitation from the dataset, the minimum value of $446 \mathrm{~mm}$ was recorded in Spain in 2005, and the highest value in Slovenia, its maximum value of $2267 \mathrm{~mm}$ corresponding to 2014.

\section{Methodology}

Based on the information obtained and the heterogeneity of the data, a panel data model was constructed to explain the road deaths over time in the selected countries. This type of model is widely used in road safety literature $[64,65,95]$. In order to detect various phenomena typical of these models, a series of tests were carried out and are shown in Table 3. Levene's test [96] was used to check homoscedasticity across cross-sections. To test for serial correlation in the idiosyncratic errors, Wooldridge's test was used [97], the null hypothesis assuming no first-order autocorrelation. Finally, to check for cross-section independence, Pesaran's test is used [98]. The results of the three tests reject the null hypothesis, so the existence of first-order autocorrelation, groupwise heteroscedasticity and contemporaneous correlation is accepted in the panel.

Table 3. Analysis of the model.

\begin{tabular}{ccc}
\hline Levene's test: & W0: F $(22,410)$ & 24.684 \\
\hline & Prob $>$ F $=$ & 0.000 \\
\cline { 2 - 3 } & W50: $\mathrm{F}(22,410)$ & 14.203 \\
\cline { 2 - 3 } & Prob $>$ F $=$ & 0.000 \\
\cline { 2 - 3 } & W10: $\mathrm{F}(22,410)$ & 23.737 \\
\hline \multirow{2}{*}{ Wooldridge's test: } & Prob $>\mathrm{F}=$ & 0.000 \\
\cline { 2 - 3 } & $\mathrm{F}(1,22)=$ & 189.506 \\
\hline Pesaran's test: & Prob $>\mathrm{F}=$ & 0.000 \\
\hline \multirow{2}{*}{} & Pesaran's test of cross-sectional independence $=$ & 5.690 \\
\cline { 2 - 3 } & Average absolute value of the off-diagonal elements $=$ & 0.400 \\
\hline
\end{tabular}

Therefore, to solve these problems and obtain robust estimators, Panel Corrected Standard Error estimators [99] were used with a first-order country-specific autocorrelation. The panel data model used takes the following form:

$$
\mathrm{y}_{i t}=\beta_{0}+\beta_{1} \mathrm{X}_{1 i t}+\beta_{2} \mathrm{X}_{2 \mathrm{it}}+\ldots+\beta_{\mathrm{K}} \mathrm{X}_{\mathrm{Kit}}+\mu_{i t}
$$

in which $y_{i t}$ represents the dependent variable, with sub-indexes $i$ for each country and $t$ for each year. $X_{\mathrm{Kit}}$ are the independent variables, $\beta_{\mathrm{K}}$ are the estimable coefficients and $\mu_{i t}$ the error term:

$$
\mu_{i t}=\rho_{\mathrm{i}} \mu_{i t-1}+\mathrm{e}_{i t},
$$

where $\rho_{i}$ are the autocorrelation parameters and $\mathbf{e}_{i t}$ corresponds to the iid error terms. The software used to estimate the model is STATA, which applies a Prais-Winsten regression to estimate the parameters. 
As a dependent variable, the fatality rate defined in the previous section was used. As independent variables, the ones defined in Table 1 were taken. These variables serve to control for the effects of the investments made, and for specific factors of transport, of socioeconomic conditions and of meteorology. Thus, the model is as follows:

$$
\begin{gathered}
\text { Fatal_pkm= } \beta_{0}+\beta_{1} \text { Road_inv_km }+\beta_{2} \text { Road_inv_km_lag } 1+\beta_{3} \text { Road_maint_km }+ \\
\beta_{4} \text { Road_maint_km_lag } 1+\beta_{5} \text { Prop_motorwa }+\beta_{6} \text { Mot_index }+ \\
\beta_{7} \text { Petrol_car }+\beta_{8} G D P+\beta_{9} \text { Unemploy }+\beta_{10} \text { Den_populat }+ \\
\beta_{11} \text { Prop_elder }+\beta_{12} \text { Precipit }+\mu_{i t} .
\end{gathered}
$$

\section{Results and Discussion}

The results of the regression are presented in Table 4 This table also shows the country-specific autocorrelation parameters, where high values can be seen in general. Statistically significant results were obtained for 7 of the 12 independent variables introduced in the model.

Table 4. Results.

\begin{tabular}{ccccccc}
\hline \multicolumn{7}{c}{ Panel-Corrected } \\
\hline Fatal_pkm & Coef. $\left(\beta_{\mathrm{K}}\right)$ & Std. Err. & $\mathrm{P}>|\mathrm{z}|$ & & $(95 \%$ Conf. Interval $)$ \\
\hline Road_inv_km & & & & & & \\
current year & -0.0006399 & 0.0046568 & 0.891 & & -0.009767 & 0.0084872 \\
one year lagged & 0.013594 & 0.0046714 & 0.004 & $* * *$ & 0.0044382 & 0.0227497 \\
\hline Road_maint_km & & & & & & \\
current year & -0.0134489 & 0.0103696 & 0.195 & & -0.0337729 & 0.0068751 \\
one year lagged & -0.0246654 & 0.0105043 & 0.019 & $* *$ & -0.0452536 & -0.0040773 \\
\hline Prop_motorwa & -0.1192364 & 0.0668657 & 0.075 & $*$ & -0.2502907 & 0.0118179 \\
Mot_index & -0.026589 & 0.0046197 & 0.000 & $* * *$ & -0.0356435 & -0.0175345 \\
Petrol_car & -0.1584325 & 0.3552821 & 0.656 & & -0.8547727 & 0.5379076 \\
GDP & -0.0006765 & 0.000294 & 0.021 & $* *$ & -0.0012527 & -0.0001003 \\
Unemploy & -0.0979118 & 0.074966 & 0.192 & & -0.2448423 & 0.0490188 \\
Den_populat & 0.0000861 & 0.002502 & 0.973 & & -0.0048178 & 0.00499 \\
Prop_elder & -0.7075401 & 0.2493493 & 0.005 & $* * *$ & -1.196256 & -0.2188245 \\
Precipit & -0.0013385 & 0.0003708 & 0.000 & $* * *$ & -0.0020652 & -0.0006118 \\
\hline
\end{tabular}

The model includes a constant term. ${ }^{*} p<0.10,{ }^{* *} p<0.05$ and ${ }^{* * *} p<0.01$. Country-specific autocorrelation parameters $\left(\rho_{\mathrm{i}}\right)$ : Austria: 0.86428; Belgium: 0.86106; Croatia: 0.83406; Czech Republic: 0.60604; Denmark: 0.94237; Estonia: 0.65279; Finland: 0.92930; France: 0.84233; Germany: 0.84264; Ireland: 0.92663; Italy: 0.90176; Latvia: 0.88750; Lithuania: 0.83727; Luxembourg: 0.78518; Netherlands: 0.93106; Norway: 0.75906; Poland: 0.87664; Portugal: 0.49922; Slovak Republic: 0.84542; Slovenia: 0.74274; Spain: 0.89541; Sweden: 0.93517; United Kingdom: 0.86897.

\subsection{Explanatory Variables for Investment in Construction and Conservation and Maintenance}

The results show a significant positive relationship for investment in road construction, only for the case with a one-year delay. This finding is in line with other studies $[50,54]$. The results suggest an increase in the death rate of 0.013594 for every thousand euros invested in the year before the one under consideration.

With respect to expenditure on road maintenance, a significant negative relationship was obtained for the variable with a one-year delay. The greater significance of the variable in the year following the one when the expenditure is made could be attributed to the fact that part of the maintenance work is carried out at the end of the year, and therefore its effects are reflected in the following year. Furthermore, its influence on mortality is almost double that of the investment in construction. The results suggest a reduction of 0.0246654 in the death rate for each thousand euros invested in maintenance and conservation during the year prior to the one considered. This favourable effect of maintenance expenditure on road safety is reflected in other studies [50,52-54]. 


\subsection{Explanatory Variables for Transport-Specific Factors}

With regard to the composition of the road infrastructure, a significant negative relationship was derived for the proportion of motorways, as seen elsewhere in the literature $[51,52,54,95]$. Albalate and Bel [95] indicated that only a greater proportion of highways in the road network had beneficial effects in reducing mortality, while the extension of the rest of the network did not clearly affect road safety. The rate of motorisation, as an indicator of a country's level of prosperity, showed a significant negative relationship. These results are consistent with previous studies $[41,50,54,100]$. Finally, fuel consumption per car was not statistically significant, which does not allow us to affirm whether a more or less intensive use of the vehicle fleet has an effect on mortality.

\subsection{Socioeconomic Variables}

Turning to the socioeconomic variables included in the model, significant negative results were obtained for GDP and the proportion of people over 65, while the unemployment rate and population density did not result significant. The beneficial effect of GDP on road accident rates may be due to the impact that a greater GDP has on improvement of the health care system and on the existence of better passive protection measures both in vehicles and in the infrastructure itself, such effects proving valid at least in high-income countries [101]. While these two characteristics do not influence the reduction of accidents, they can play an important role in reducing deaths. The negative relationship between the proportion of people over 65 and the mortality rate has been indicated in previous studies [52,54]. This sector of the population, in addition to having more driving experience, tends to take fewer risks. One explanation may be a perceived decrease in their skills, leading to greater self-regulation in driving [102]. Yet such self-regulatory behaviour would also give rise to a progressive increase in driving avoidance with age [103], implying some impact on reducing road accidents.

\subsection{Meteorological Variables}

Finally, the average annual precipitation, as a meteorological variable, is significant and has a negative sign. This relationship has been previously documented and is considered to be the result of greater driving caution in the presence of rain [51,69].

\section{Conclusions}

This study has analysed the influence of the economic resources invested in roads, for both their construction and for their maintenance and conservation, on road casualties. A panel data model was elaborated with information from 23 European countries for the period between 1998 and 2016. Fatality rate was used as a dependent variable to adjust the number of deaths in traffic accidents on interurban roads to the level of exposure in each country. As independent variables, in addition to the resources invested in roads, and due to the complexity of the problem to be addressed, a series of variables related to transport-specific, socioeconomic and meteorological factors was included, giving a total of seven significant ones.

The results presented here show that spending on road maintenance and conservation has a positive effect on road safety, reducing the death rate especially in the year following the year in which the expenditure was made. Thus, spending on road maintenance and conservation has a positive impact on society, beyond that of preventing deterioration of the infrastructure and prolonging its useful life-it contributes to reducing road deaths, thereby providing the added value of a safer and more sustainable transport system. This evidence is particularly relevant now, as ambitious new targets are being set for 2030 by EU member countries, such as a $50 \%$ reduction in the number of fatalities and serious injuries from the 2020 baseline.

Our findings may therefore be very useful for policy makers and budget planners within a "Safe System" approach. Recommended worldwide by the World Health Organization and progressively adopted in all EU countries, regions and municipalities, this approach upholds the overriding objective 
of addressing the causes of accidents in an integrated way, building layers of protection that ensure that, if one element fails, another will compensate [104]. Accordingly, spending on road maintenance and conservation would function as a layer of protection for drivers.

In terms of investment in road construction, the results show that its increase would lead to an increase in road mortality. On the other hand, the composition of the road infrastructure network also has a significant influence on the mortality rate in road accidents. Our results show that a higher proportion of motorways would induce lower death rates, the reason being that motorways entail better technical characteristics and greater traffic capacity. Motorways have a lower fatality rate than conventional roads, with 7\% of all fatalities on motorways in the EU between 2006 and 2015 [105], demonstrating the road safety benefits of motorway construction.

In addition to the above, increases in the motorisation rate, GDP, the proportion of people over 65 years old, or average annual rainfall lead to a reduction in the number of road fatalities.

Finally, it should be noted that this study has certain limitations to be taken into account in order to strengthen future lines of research. Firstly, with regard to the independent variables introduced in the model, no control was included for legislative changes that could affect road safety during the study period. Albalate et al. [52] warned that if such legislative changes were not included in the model, the results of the impact of road construction on road accident rates might be inconclusive. However, this did not affect the representativeness of the beneficial effects on road safety of expenditure for maintenance and conservation. Therefore, before drawing conclusions about the effects of investing in road construction, it would be advisable to include this aspect, not considered here. Another variable that presents certain limitations is population density. Indeed, the results do not show it to be statistically significant. The limiting factor of population density data is that they do not necessarily represent the urban or rural structure of a country accurately. This is because the calculation of these data is conditioned by the total area of a given country, rather than by the area actually occupied. Notwithstanding, and in view of the lack of data on built-up areas in Europe (available only for the years 2009, 2012 and 2015 in Eurostat), the authors decided to use the definition of number of inhabitants per surface area of the country, as presented in various studies cited above.

Author Contributions: F.C.-P., J.N.-M. and J.d.O. contributed equally to the different tasks and parts of the paper. All authors have read and agreed to the published version of the manuscript.

Funding: The authors wish to express their gratitude to the Ministry of Science, Innovation and Universities for funding received for the project "INVERSIÓN EN CARRETERAS Y SEGURIDAD VIAL: UN ANÁLISIS INTERNACIONAL (INCASE)", reference RTI2018-101770-B-I00, within the State Programme for R+D+i Oriented to the Challenges of Society.

Acknowledgments: The authors would like to thanks the International Transport Forum (ITF), the Ministry of Transport, Mobility and Urban Agenda of Spain (MITMA) and the Federal Ministry of Transport and Digital Infrastructure of Germany (BMVI) for the data provided for the study.

Conflicts of Interest: The authors declare no conflict of interest.

\section{References}

1. World Health Organization (WHO). Global Status Report on Road Safety 2018; World Health Organization: Geneva, Switzerland, 2018; ISBN 978-92-4-156568-4.

2. European Transport Safety Council (ETSC). Briefing: EU Strategic Action Plan on Road Safety; European Transport Safety Council: Brussels, Belgium, 2019.

3. European Transport Safety Council (ETSC). Ranking EU Progress. In 13th Road Safety Performance Index Report; European Transport Safety Council: Brussels, Belgium, 2019.

4. European Commission. Directorate General for Transport. In Annual Accident Report 2018; The European Road Safety Observatory: Brussels, Belgium, 2018.

5. Elvik, R. How much do road accidents cost the national economy? Accid. Anal. Prev. 2000, 32, 849-851. [CrossRef]

6. Wijnen, W.; Stipdonk, H. Social costs of road crashes: An international analysis. Accid. Anal. Prev. 2016, 94, 97-106. [CrossRef] [PubMed] 
7. European Commission. Directorate General for Mobility and Transport. In Handbook on the External Costs of Transport; Publications Office of the European Union: Belgium, Brussels, 2019; ISBN 9789279969171.

8. European Investment Bank. Restoring EU Competitiveness; European Investment Bank: Luxembourg, 2016.

9. European Commission. Overview of Transport Infrastructure Expenditures and Costs; Publications Office of the European Union: Brussels, Belgium, 2019; ISBN 9789279969201.

10. World Bank Group. World Bank Country and Lending Groups. Available online: http://databank.worldbank. org/data/download/site-content/CLASS.xls (accessed on 20 April 2020).

11. Elvik, R.; Høye, A.; Vaa, T.; Sørensen, M. The Handbook of Road Safety Measures; Emerald Group Publishing Limited: Bingley, UK, 2009; ISBN 978-1-84855-250-0.

12. Abdel-Aty, M.A.; Essam Radwan, A. Modeling traffic accident occurrence and involvement. Accid. Anal. Prev. 2000, 32, 633-642. [CrossRef]

13. Caliendo, C.; Guida, M.; Parisi, A. A crash-prediction model for multilane roads. Accid. Anal. Prev. 2007, 39, 657-670. [CrossRef] [PubMed]

14. Dong, C.; Nambisan, S.; Richards, S.H.; Ma, Z. Assessment of the effects of highway geometric design features on the frequency of truck involved crashes using bivariate regression. Transp. Res. Part A Policy Pract. 2015, 75, 30-41. [CrossRef]

15. Haynes, R.; Jones, A.; Kennedy, V.; Harvey, I.; Jewell, T. District Variations in Road Curvature in England and Wales and their Association with Road-Traffic Crashes. Environ. Plan. A Econ. Space 2007, 39, 1222-1237. [CrossRef]

16. Kononov, J.; Bailey, B.; Allery, B.K. Relationships between safety and both congestion and number of lanes on urban freeways. Transp. Res. Rec. 2008, 2083, 26-39. [CrossRef]

17. Mujalli, R.O.; de Oña, J. A method for simplifying the analysis of traffic accidents injury severity on two-lane highways using Bayesian networks. J. Saf. Res. 2011, 42, 317-326. [CrossRef]

18. De Oña, J.; López, G.; Mujalli, R.; Calvo, F. Analysis of traffic accidents on rural highways using Latent Class Clustering and Bayesian Networks. Accid. Anal. Prev. 2013, 51, 1-10. [CrossRef]

19. Garach, L.; Calvo, F.; Pasadas, M.; De Oña, J. Proposal of a new global model of consistency: Application in two-lane rural highways in Spain. J. Transp. Eng. 2014, 140. [CrossRef]

20. Chan, C.Y.; Huang, B.; Yan, X.; Richards, S. Investigating effects of asphalt pavement conditions on traffic accidents in Tennessee based on the pavement management system (PMS). J. Adv. Transp. 2010, 44, 150-161. [CrossRef]

21. Edwards, J.B. Wind-related road accidents in England and Wales 1980-1990. J. Wind. Eng. Ind. Aerodyn. 1994, 52, 293-303. [CrossRef]

22. Brijs, T.; Karlis, D.; Wets, G. Studying the effect of weather conditions on daily crash counts using a discrete time-series model. Accid. Anal. Prev. 2008, 40, 1180-1190. [CrossRef] [PubMed]

23. Hanbali, R.M. Maintenance of the Highway Infrastructure. Transp. Res. Rec. 1994, 1442, 151-161.

24. Norrman, J.; Eriksson, M.; Lindqvist, S. Relationships between road slipperiness, traffic accident risk and winter road maintenance activity. Clim. Res. 2000, 15, 185-193. [CrossRef]

25. Chiou, Y.C.; Fu, C. Modeling crash frequency and severity using multinomial-generalized Poisson model with error components. Accid. Anal. Prev. 2013, 50, 73-82. [CrossRef]

26. Elvik, R.; Christensen, P.; Amundsen, A. Speed and Road Accidents: An evaluation of the Power Model; The Institute of Transport Economics (TOI): Oslo, Norway, 2004; ISBN 82-480-0451-1.

27. Aarts, L.; van Schagen, I. Driving speed and the risk of road crashes: A review. Accid. Anal. Prev. 2006, 38, 215-224. [CrossRef]

28. Hassan, H.M.; Abdel-Aty, M.A. Exploring the safety implications of young drivers' behavior, attitudes and perceptions. Accid. Anal. Prev. 2013. [CrossRef]

29. Evans, L. Traffic Safety and the Driver; Van Nostrand Reinhold: New York, NY, USA, 1991; ISBN 0-442-00163-0.

30. Constantinou, E.; Panayiotou, G.; Konstantinou, N.; Loutsiou-Ladd, A.; Kapardis, A. Risky and aggressive driving in young adults: Personality matters. Accid. Anal. Prev. 2011, 43, 1323-1331. [CrossRef]

31. Holubowycz, O.T.; Kloeden, C.N.; McLean, A.J. Age, sex, and blood alcohol concentration of killed and injured drivers, riders, and passengers. Accid. Anal. Prev. 1994, 26, 483-492. [CrossRef]

32. Nordbakke, S.; Sagberg, F. Sleepy at the wheel: Knowledge, symptoms and behaviour among car drivers. Transp. Res. Part F Traffic Psychol. Behav. 2007, 10, 1-10. [CrossRef] 
33. Zhang, T.; Chan, A.H.S. Sleepiness and the risk of road accidents for professional drivers: A systematic review and meta-analysis of retrospective studies. Saf. Sci. 2014, 70, 180-188. [CrossRef]

34. Hedlund, J.; Arnold, R.; Cerrelli, E.; Partyka, S.; Hoxie, P.; Skinner, D. An assessment of the 1982 traffic fatality decrease. Accid. Anal. Prev. 1984, 16, 247-261. [CrossRef]

35. Hoxie, P.; Skinner, D.; Wang, H. Socio-Economic Influences on Highway Fatalities: An Empirical Investigation; National Highway Traffic Safety Administration: Washington, DC, USA, 1984.

36. Partyka, S.C. Simple models of fatality trends using employment and population data. Accid. Anal. Prev. 1984, 16, 211-222. [CrossRef]

37. Wagenaar, A.C. Effects of macroeconomic conditions on the incidence of motor vehicle accidents. Accid. Anal. Prev. 1984, 16, 191-205. [CrossRef]

38. Joksch, H.C. The relation between motor vehicle accident deaths and economic activity. Accid. Anal. Prev. 1984, 16, 207-210. [CrossRef]

39. Kopits, E.; Cropper, M. Traffic fatalities and economic growth. Accid. Anal. Prev. 2005. [CrossRef]

40. Hakim, S.; Shefer, D.; Hakkert, A.S.; Hocherman, I. A critical review of macro models for road accidents. Accid. Anal. Prev. 1991, 23, 379-400. [CrossRef]

41. Kweon, Y.-J. What affects annual changes in traffic safety? A macroscopic perspective in Virginia. J. Saf. Res. 2015, 53, 17-21. [CrossRef]

42. Lloyd, L.; Wallbank, C.; Broughton, J. A collection of evidence for the impact of the economic recession on road fatalities in Great Britain. Accid. Anal. Prev. 2015, 80, 274-285. [CrossRef]

43. Rivas-Ruiz, F.; Perea-Milla, E.; Jimenez-Puente, A. Geographic variability of fatal road traffic injuries in Spain during the period 2002-2004: An ecological study. BMC Public Health 2007, 7. [CrossRef]

44. Michalaki, P.; Quddus, M.; Pitfield, D.; Huetson, A. A time-series analysis of motorway collisions in England considering road infrastructure, socio-demographics, traffic and weather characteristics. J. Transp. Health 2016, 3, 9-20. [CrossRef]

45. Cafiso, S.; Di Graziano, A.; Di Silvestro, G.; La Cava, G.; Persaud, B. Development of comprehensive accident models for two-lane rural highways using exposure, geometry, consistency and context variables. Accid. Anal. Prev. 2010, 42, 1072-1079. [CrossRef] [PubMed]

46. Elvik, R. The safety value of guardrails and crash cushions: A meta-analysis of evidence from evaluation studies. Accid. Anal. Prev. 1995, 27, 523-549. [CrossRef]

47. He, M.M. Driving through the Great Recession: Why does motor vehicle fatality decrease when the economy slows down? Soc. Sci. Med. 2016, 155, 1-11. [CrossRef] [PubMed]

48. Noland, R.B.; Zhou, Y. Has the great recession and its aftermath reduced traffic fatalities? Accid. Anal. Prev. 2017, 98, 130-138. [CrossRef]

49. Wegman, F.; Allsop, R.; Antoniou, C.; Bergel-Hayat, R.; Elvik, R.; Lassarre, S.; Lloyd, D.; Wijnen, W. How did the economic recession (2008-2010) influence traffic fatalities in OECD-countries? Accid. Anal. Prev. 2017, 102, 51-59. [CrossRef]

50. Fridstrøm, L.; Ingebrigtsen, S. An aggregate accident model based on pooled, regional time-series data. Accid. Anal. Prev. 1991, 23, 363-378. [CrossRef]

51. Aparicio Izquierdo, F.; Arenas Ramírez, B.; Bernardos Rodríguez, E. The interurban DRAG-Spain model: The main factors of influence on road accidents in Spain. Res. Transp. Econ. 2013, 37, 57-65. [CrossRef]

52. Albalate, D.; Fernández, L.; Yarygina, A. The road against fatalities: Infrastructure spending vs. regulation? Accid. Anal. Prev. 2013, 59, 227-239. [CrossRef]

53. Nguyen-Hoang, P.; Yeung, R. Dollars for lives: The effect of highway capital investments on traffic fatalities. J. Saf. Res. 2014, 51, 109-115. [CrossRef]

54. González, M.P.S.; Sotos, F.E.; Ponce, Á.T. Impact of provincial characteristics on the number of traffic accident victims on interurban roads in Spain. Accid. Anal. Prev. 2018, 118, 178-189. [CrossRef] [PubMed]

55. Hakkert, S.; Braimaister, L. The Uses of Exposure and Risk in Road Safety Studies; The SWOV Institute for Road Safety Research: Leidschendam, The Netherlands, 2002.

56. Farchi, S.; Molino, N.; Rossi, P.G.; Borgia, P.; Krzyzanowski, M.; Dalbokova, D.; Kim, R. Defining a common set of indicators to monitor road accidents in the European Union. BMC Public Health 2006, 6, 1-12. [CrossRef] [PubMed]

57. Lamm, R.; Choueiri, E.M.; Kloeckner, J.H. Accidents in the U.S. and Europe: 1970-1980. Accid. Anal. Prev. 1985, 17, 429-438. [CrossRef] 
58. Papadimitriou, E.; Yannis, G.; Bijleveld, F.; Cardoso, J.L. Exposure data and risk indicators for safety performance assessment in Europe. Accid. Anal. Prev. 2013, 60, 371-383. [CrossRef] [PubMed]

59. OECD/Eurostat/UN ECE. Illustrated Glossary for Transport Statistics, 4th ed.; OECD Publishing: Paris, France, 2010; ISBN 9789282102947.

60. Fridstrøm, L.; Ifver, J.; Ingebrigtsen, S.; Kulmala, R.; Thomsen, L.K. Measuring the contribution of randomness, exposure, weather, and daylight to the variation in road accident counts. Accid. Anal. Prev. 1995, 27, 1-20. [CrossRef]

61. Scuffham, P. Economic factors and traffic crashes in New Zealand. Appl. Econ. 2003, 35, 179-188. [CrossRef]

62. Anastasopoulos, P.C.; Mannering, F.L.; Shankar, V.N.; Haddock, J.E. A study of factors affecting highway accident rates using the random-parameters tobit model. Accid. Anal. Prev. 2012, 45, 628-633. [CrossRef]

63. García-Ferrer, A.; De Juan, A.; Poncela, P. The relationship between road traffic accidents and real economic activity in Spain: Common cycles and health issues. Health Econ. 2007, 16, 603-626. [CrossRef]

64. Yannis, G.; Papadimitriou, E.; Folla, K. Effect of GDP changes on road traffic fatalities. Saf. Sci. 2014, 63, 42-49. [CrossRef]

65. Antoniou, C.; Yannis, G.; Papadimitriou, E.; Lassarre, S. Relating traffic fatalities to GDP in Europe on the long term. Accid. Anal. Prev. 2016, 92, 89-96. [CrossRef] [PubMed]

66. Noland, R.B.; Oh, L. The effect of infrastructure and demographic change on traffic-related fatalities and crashes: A case study of Illinois county-level data. Accid. Anal. Prev. 2004, 36, 525-532. [CrossRef]

67. Eksler, V.; Lassarre, S.; Thomas, I. Regional analysis of road mortality in Europe. Public Health 2008, 122, 826-837. [CrossRef] [PubMed]

68. Calderón, J.L.R.; de Dios Luna del Castillo, J.; Jiménez Moleón, J.J.; Lardelli Claret, P.; Gálvez Vargas, R. Variabilidad geográfica de la gravedad de los accidentes de tráfico en España. Gac. Sanit. 2000, 14, 16-22. [CrossRef]

69. Eisenberg, D. The mixed effects of precipitation on traffic crashes. Accid. Anal. Prev. 2004, 36, 637-647. [CrossRef]

70. Theofilatos, A.; Yannis, G. A review of the effect of traffic and weather characteristics on road safety. Accid. Anal. Prev. 2014, 72, 244-256. [CrossRef]

71. World Bank Group. World Bank Open Data. Available online: https://data.worldbank.org/ (accessed on 30 April 2020).

72. United Nations Economic Commission for Europe (UNECE). Statistical Database. Available online: https://w3.unece.org/PXWeb2015/pxweb/en/STAT/STAT_40-TRTRANS/?rxid=18ad5d0d-bd5e-476f-ab7c40545e802eeb (accessed on 28 April 2020).

73. European Commission. Fatalities as Reported by Age Group in EU Countries. 2018. Available online: https://ec.europa.eu/transport/road_safety/sites/roadsafety/files/pdf/statistics/historical_ country_age_group.pdf (accessed on 28 April 2020).

74. OECD/ITF IRTAD Database. Available online: https://stats.oecd.org/ (accessed on 28 April 2020).

75. Ministerstvo Vnútra-Slovenskey Republiky Kompletná štatistika. Available online: https://www.minv.sk/ ?kompletna-statistika (accessed on 28 April 2020).

76. European Commission EU Transport in Figures-Statistical Pocketbooks. Available online: https://ec.europa. eu/transport/facts-fundings/statistics_en (accessed on 28 April 2020).

77. International Transport Forum. OECD iLibrary-Transport Infrastructure Investment and Maintenance. Available online: https://doi.org/10.1787/g2g55573-en (accessed on 28 April 2020).

78. Radke, S. Verkehr in Zahlen 2003/2004; Bundesministerium für Verkehr und digitale Infrastruktur: Hamburg, Germany, 2004; ISBN 3871542946.

79. Radke, S. Verkehr in Zahlen 2018/2019. In Verkehrsdynamik; Bundesministerium für Verkehr und digitale Infrastruktur: Flensburg, Germany, 2018; ISBN 9783000612947.

80. Ministerie van Infrastructuur en Milieu. Rijksjaarverslag 2014 a Infrastructuurfonds; Ministerie van Infrastructuur en Milieu: The Hague, The Netherlands, 2015; ISNN 0921-7371.

81. Ministerie van Infrastructuur en Waterstaat. Rijksjaarverslag 2018 a Infrastructuurfonds; Ministerie van Infrastructuur en Waterstaat: The Hague, The Netherlands, 2019; ISNN 0921-7371.

82. Ministério da Economia. Base de Dados de Infraestruturas. Available online: https://www.gee.gov.pt/pt/ publicacoes/indicadores-e-estatisticas/base-de-dados-de-infraestruturas (accessed on 30 April 2020).

83. Porto, U. Relatório e Contas 2010; Estradas de Portugal S.A.: Lisboa, Portugal, 2011. 
84. De Contas, R.D.A.A. Relatório e Contas 2011; Estradas de Portugal S.A.: Almada, Portugal, 2012.

85. Millennium, B.C.P. Relatório E Contas 2013; Estradas de Portugal S.A.: Almada, Portugal, 2013.

86. De Contas, R.D.A.A. Relatório e Contas 2015; Infraestruturas de Portugal S.A.: Pragal, Portugal, 2016.

87. Portugal, N.A.V. Relatório e Contas 2018; Infraestruturas de Portugal S.A.: Almada, Portugal, 2019.

88. Ministerio de Fomento. Dirección General de Programación Económica y Presupuestos. In Subdirección General de Estudios Económicos y Estadísticas Serie: Anuario Estadístico; Annual; Centro de Publicaciones. Secretaría General Técnica; NIPO 161-13-171-0; Ministerio de Fomento: Madrid, Spain, 2013.

89. Centrum Dopravního Výzkumu. Ministerstvo Dopravy Ročenka Dopravy; Ročenka dopravy; Centrum Dopravního Výzkumu: Prague, Czech Republic, 2017; ISSN: 1801-3090.

90. Trafikverket. The Swedish Transport Administration Annual Report: 2017; Trafikverket: Borlänge, Sweden, 2018; ISBN 978-91-7725-272-6.

91. Main Economic Indicators (database). Available online: https://data.oecd.org/ (accessed on 30 April 2020).

92. European Commission Database-Eurostat. Available online: https://ec.europa.eu/eurostat/data/database (accessed on 28 April 2020).

93. Copernicus Climate Change Service Climate Data for the European Energy Sector from 1979 to 2016 Derived from ERA-Interim. Available online: https://cds.climate.copernicus.eu/cdsapp\#!/dataset/sis-europeanenergy-sector?tab=overview (accessed on 29 April 2020).

94. Pereira, A.M.; Pereira, R.M. Investimentos em Infra-Estruturas em Portugal; Fundação Francisco Manuel dos Santos: Lisboa, Portugal, 2016; ISBN 9789898838568.

95. Albalate, D.; Bel, G. Motorways, tolls and road safety: Evidence from Europe. Series 2012, 3, $457-473$. [CrossRef]

96. Levene, H. Robust tests for equality of variances. In Contributions to Probability and Statistics: Essays in Honor of Harold Hotelling; Stanford University Press: Palo Alto, CA, USA, 1960.

97. Wooldridge, J.M. Diagnostic Testing. In A Companion to Theoretical Econometrics; Blackwell Publishing Ltd: Malden, MA, USA, 2007; pp. 180-200. ISBN 9780470996249.

98. Pesaran, M.H. General diagnostic tests for cross section dependence in panels. Empir Econ. 2020. [CrossRef]

99. Beck, N.; Katz, J.N. What To Do (and Not to Do) with Time-Series Cross-Section Data. Am. Polit. Sci. Rev. 1995, 89, 634-647. [CrossRef]

100. Castillo-Manzano, J.I.; Castro-Nuño, M.; Fageda, X. Can cars and trucks coexist peacefully on highways? Analyzing the effectiveness of road safety policies in Europe. Accid. Anal. Prev. 2015, 77, 120-126. [CrossRef]

101. Bishai, D.; Quresh, A.; James, P.; Ghaffar, A. National road casualties and economic development. Health Econ. 2006, 15, 65-81. [CrossRef] [PubMed]

102. Langford, J.; Methorst, R.; Hakamies-Blomqvist, L. Older drivers do not have a high crash risk-A replication of low mileage bias. Accid. Anal. Prev. 2006, 38, 574-578. [CrossRef] [PubMed]

103. Gabaude, C.; Marquié, J.-C.; Obriot-Claudel, F. Self-regulatory driving behaviour in the elderly: Relationships with aberrant driving behaviours and perceived abilities. Trav. Hum. 2010, 73, 31. [CrossRef]

104. European Commission. EUROPE ON THE MOVE. Sustainable Mobility for Europe: Safe, connected, and clean; COM(2018) 293 final; EU Publications: Brussels, Belgium, 2018.

105. European Commission. Directorate General for Transport Traffic Safety Basic Facts 2017. Motorways 2017; The European Road Safety Obseravtory: Brussels, Belgium, 2018.

(C) 2020 by the authors. Licensee MDPI, Basel, Switzerland. This article is an open access article distributed under the terms and conditions of the Creative Commons Attribution (CC BY) license (http://creativecommons.org/licenses/by/4.0/). 